\title{
A commentary on recent water safety initiatives in the context of water utility risk management
}

\author{
Paul D. Hamilton ${ }^{\mathrm{a}^{*}}$, Paul Gale ${ }^{\mathrm{b}}$ and Simon J.T. Pollard ${ }^{\mathrm{a}}$ \\ ${ }^{a}$ Sustainable Systems Department, School of Industrial and Manufacturing Science, Cranfield University, \\ Cranfield, Bedfordshire, MK43 OAL, United Kingdom \\ ${ }^{b} 59$, Fairway Avenue, Tilehurst, Reading, Berkshire, RG30 4QB, United Kingdom
}

\section{Abstract} product monitoring to ensure safe water quality and have sought to reinforce their approach by adopting preventative strategies where risks are proactively identified, assessed and managed. This is leading to the development of water safety plans; structured 'route maps' for managing risks to water supply, from catchment to consumer taps. This paper reviews the Hazard Analysis and Critical Control Point (HACCP) procedure on which many water safety plans are based and considers its appropriateness in the context of drinking water risk management. We examine water safety plans in a broad context, looking at a variety of monitoring, optimisation and risk management initiatives that can be taken to improve drinking water safety. These are cross-compared using a simple framework that facilitates an integrated approach to water safety. Finally, we look at how risk management practices are being integrated across water companies and how this is likely to affect the future development of water safety plans.

Keywords: water safety plans, HACCP, risk assessment, Cryptosporidium, water quality.

\section{Introduction and context}

Internationally, the last two decades have witnessed a large number of microbial and chemical contamination incidents (Table 1), many of which have led to illness and even fatalities in the community. In developed countries, the most serious of these was the 1993 cryptosporidiosis outbreak in Milwaukee (Lisle and Rose, 1995; Solo-Gabriele and Neumeister, 1996; Deininger, 2004; Hrudey and Hrudey, 2004). Cryptosporidium parvum is a human and animal pathogen that has exhibited some resistance to the conventional water disinfection method of chlorination (Smith et al., 1990). Water companies have therefore

\footnotetext{
" Corresponding author. Tel: +44 (0) 1234750111 x 2570; Fax: +44 (0) 1234751 671. Email address: p.hamilton@cranfield.ac.uk
} 
1 sought to minimize the risk of contamination by ensuring the organism's physical removal from drinking water supplies. In examining the cause of the Milwaukee outbreak, studies such as Lisle and Rose (1995) highlighted a number of flaws in the design and operation at the treatment plant in question; not least a prolonged period of poor coagulation control and filter performance, evidenced by vast increases in the measured turbidity of water leaving the works. This and other diagnosed incidents in Australia, Canada, Japan, UK, and the USA (Baudin and Lainé, 1998) have led to an increased global awareness of the potential consequences of waterborne cryptosporidiosis and other microbial diseases and have reinforced the need to maintain high standards of process design and operation at vulnerable water treatment works.

Table 1

Some documented water quality incidents

A further defining moment was the 1998 Cryptosporidium crisis in Sydney (McClellan, 1998; Cunliffe, 2003; Hrudey and Hrudey, 2004). A 'boil water' notice was issued after a high concentration of Giardia cysts and Cryptosporidium oocysts were found in raw and treated waters. Fortunately, the pathogens were found to be inactive and no illness in the community resulted, although it did serve as a wake-up call for the industry, both in terms of catchment management and the way risks are communicated to the public. For commentators such as Deere and Davison (1998) and Cunliffe (2003), the Sydney incident highlighted the limitations of management based purely on end-product monitoring, and the lack of a coordinated approach to dealing with water quality. Soon after, another incident, this time resulting in fatalities, took place in Walkerton (Canada) in 2000. Here, the water supply became contaminated with microbial pathogens after manure was spread on a farm near a public supply well. More than 2,300 people became ill and seven people died. The official inquiry (O’Connor, 2002) reported a litany of bad practice prior to and during the incident including the failure of operational staff to maintain effective chlorination of the water supply and carry out routine chlorine residual checks, the falsification of water quality records by staff and the failure of treatment managers to respond satisfactorily to positive microbial tests, any one of which may have significantly reduced the impact of the incident or prevented it altogether. The official report into the Walkerton incident (O’Connor, 2002) recommended that water suppliers adopt a Total Quality Management system based upon 
- the adoption of best practices and continuous improvement;

- 'real time' process control (e.g. continuous monitoring of turbidity, chlorine residual, and disinfectant contact time) wherever feasible;

- the effective operation of robust multiple barriers to protect public health;

- preventative rather than strictly reactive strategies to identify and manage risks to public health; and

- effective leadership.

Providing safe drinking water requires sound risk management. This is recognised in, and forms the central feature of, the recent revision to the WHO's (World Health Organisation's) drinking water guidelines (WHO, 2004). The rationale for this approach is that delivering safe water is not just about achieving a high level of compliance (Walker, 2005). Water supply systems can attain this and yet can still have serious latent flaws in their design or operation that are 'accidents waiting to happen'. These may include uncontrolled contamination hazards in water catchments, flaws in treatment design, leaks in distribution systems, and bad operational practices.

Water safety plans are frameworks or 'route maps' that set out preventative, step by step processes for managing water contamination risks. At an international workshop in Bonn, recommendations were made, with the aim of providing "good, safe drinking water that has the trust of customers" (AWWA et al., 2001). Key principles were set out for creating an integrated approach to water safety across the four stages of water supply: (a) catchment, (b) treatment, (c) distribution and (d) customer plumbing systems. It was also recognised, that close cooperation is required between water suppliers, governments, health agencies, environmental agencies, land users and other stakeholder groups to maintain and promote drinking water safety. After a second workshop in 2004, the Bonn Charter was published (IWA, 2004), setting out high level frameworks describing both the operational and institutional arrangements for managing water supplies.

One country that has driven much of the development of water safety plans is Australia. In 1996, the National Health and Medical Research Council (NHMRC) revised its Australian Drinking Water Guidelines (NHMRC, 1996). This highlighted that testing does not guarantee the safety of water supplies (as it is quite possible that contamination will occur between sampling events) and stressed the importance of additionally maintaining 'effective barriers to prevent contamination of the water supply system.' In 2001, the NHMRC released its 'Framework for Management of Drinking Water Quality' (NHMRC, 2001). The Framework 
1 listed a sequence of 12 elements it considered to be good practice for the management of drinking water

2 supplies from catchment to consumer. In 2002, the NHMRC provisionally redrafted its guidelines (NHMRC,

3 2002), incorporating the Framework's 12 elements as its focus. An amended draft was officially endorsed two years later (NHMRC, 2004). This was intended to introduce a standard approach throughout the industry and establish due diligence and credibility. The process is divided up into four main sections:

- $\quad$ a commitment to drinking water quality management;

- $\quad$ system analysis and management;

- $\quad$ supporting requirements e.g. employee training, community involvement, research and development, systems for documenting and reporting etc.; and

- review.

In a field that is largely practitioner-led, the development and implementation of water safety plans have varied widely. The following study considers several different approaches to water safety planning and proposes a conceptualisation that brings water safety plans and other quality management initiatives together under a single umbrella. Finally it looks briefly at wider risk management practices carried out by the industry. Utilities are seeking to adopt a more consistent, integrated approach to managing risks across their organisations, a trend which is likely to further affect the development of water safety plans.

\section{Hazard Analysis and Critical Control Point (HACCP) approach} published to date have been based on adaptive forms of the HACCP procedure. Its application within the water sector has been widely discussed in the literature (e.g. Havelaar, 1994; Deere and Davison, 1998; Deere et al., 2001; Stevens, 2003; Hrudey and Hrudey, 2004). In brief, HACCP was developed by the US Space Agency in the 1960s to ensure the safe manufacture of foodstuffs to be used in spaceflight. It was quickly implemented across the food industry, and in principle, provides a hazard-based monitoring system for protecting water supplies from different contaminants. In 1997, the Codex Alimentarius Commission released its most recent guidelines for HACCP application within the food industry (CAC, 1997), restating its seven key principles: 
2. Determine the critical control points (CCP).

3. Establish critical limit(s).

4. Establish a system to monitor control of the CCP.

5. Establish the corrective action to be taken when monitoring indicates that a particular CCP is not under control.

6. Establish procedures for verification to confirm that the HACCP system is working effectively.

7. Establish documentation concerning all procedures and records appropriate to these principles and their application.

HACCP promotes the proactive management of hazards through the identification of 'critical control points' where they can be monitored and reduced. Its application to drinking water supplies was first described in the Netherlands by Havelaar (1994). Since then it has gained some prominence internationally, but has been championed, in particular, by the Australian water industry. Following the 1998 Cryptosporidium crisis in Sydney, Deere and Davison (1998) argued that Sydney Water should adopt a full HACCP system as the most cost-effective means of assuring drinking water safety, pointing out that the UK system of increased end-product monitoring (for Cryptosporidium) had been designed primarily for legal reasons and not specifically to protect the public.

In terms of water safety, a limitation of the HACCP methodology, as originally conceived, is that it is largely concerned with hazards, not risks. Hrudey and Hrudey (2004) acknowledge that "a formalized structure has evolved with HACCP in the food industry and the prospect of (water suppliers) being HACCPcertified is appealing. These considerations need not be an impediment to effective application of the useful HACCP principles. The caution is that HACCP must be sensibly and pragmatically adapted to identify hazards and then to assess and manage their associated risks for drinking water systems". This perceived weakness was partially addressed by CAC (1997), at least in principle, which recommended that an assessment of hazard severity and likelihood could be conducted as part of the 'hazard analysis' process. Indeed, the most credible advocates of the HACCP procedure for drinking water systems such as Mullenger et al. (2002) and Hellier (2003) have also extended their plans to incorporate elements of risk assessment, typically employing a semi-quantitative method for ranking likelihood and consequence of initiating events. 
2 of the technical, managerial and humans systems within which risks may be realised (Pollard et al., 2005).

3 NHMRC (2004) point out that HACCP's scope and application is limited in several important areas such as

4 employee training, emergency response and community involvement. As they concede, however, HACCP

5 was never designed to be a fully comprehensive management system, but was intended to be added on to

6 existing, good management practices. The NHRMC (2004) Framework therefore draws not only from

7 HACCP, but also from other established systems such as ISO 9001 (ISO, 2000) and AS/NZS 4360 (AS/NZS,

8 1999) and is itself designed to be flexible and be integrated with other programmes and systems already

9 present in organisations. Thus, although HACCP can be considered to be a blueprint for many water safety

10 plans, it has also been largely superseded by these newer frameworks.

11 Another contentious issue regarding HACCP is the question of how readily the concept of CCPs can

12 be transferred to the water industry. Codex Alimentarius Commission (1997) defines a CCP as "a step at

13 which control can be applied and is essential to prevent or eliminate a food safety hazard or reduce it to an

14 acceptable level." When trying to apply this within the context of water safety, however, it is sometimes

15 difficult to gauge the criticality of the CCP i.e. what determines a control as 'essential'. Nokes and Taylor

16 (2003), for example, have argued that by concentrating on CCPs, water suppliers may perceive that they need

17 to identify only a limited number of control points at the expense of a wide range of other 'preventative

18 measures' that may also be important in reducing risk. Another potential difficulty with using HACCP

19 directly within the water industry is that the concepts of 'control points' and 'critical limits' tend to be viable

20 only when applied to treatment processes (Hellier, 2003; Nokes and Taylor, 2003), which are amenable to,

21 and thus receive a more intense, varied and quantitative level of monitoring than other stages in the water

22 supply chain; catchment management, for example.

Despite this, however, advocates of HACCP’s such as Mullenger et al. (2002) and Hellier (2003)

24 maintain that its application can yield several advantages to drinking water safety. In the case of Melbourne

25 Water, Hellier (2003) concludes that their resulting HACCP document became a road-mapping of all the

26 systems that control drinking water quality and due to the introduction of regular auditing became a driving

27 force for improving systems. In particular, Hellier cites five areas of improvement:

28 - the development of 15 new operational procedures; 
- an evaluation of catchdrains around reservoirs;

- an adjustment of treatment plant alarm settings;

- documentation of corrective actions plans; and

- training of operators on response levels to alarms at critical sites. Similarly, Mullenger et al. (2002) relate positive experiences from South East Water’s (Australia) implementation of a HACCP plan across all of its water operations. Although staff were initially 'unenthusiastic' about the initiative, its adoption appeared to lead to an increase in knowledge and understanding of the water supply system at all levels and an improved ability to identify hazards to water quality or supply. This is a frequently cited outcome of many such management systems in that the analysis itself reveals enhanced knowledge of system behaviour and vulnerability. This had led to a number of changes to operating procedures.

Another example is presented in Metge et al. (2003), who describe the application of HACCP on three critical plants on the Morsang sur Seine River in France. Their analysis realised three key hazardous events:

- aluminium contamination due to coagulant overfeeding;

- microbiological contamination due to chlorine underfeeding; and

- microbiological contamination due to chlorine dysfunction.

Critical limits were set for chlorine and residual aluminium concentrations. Although it is possible that this exercise did provide some benefit (e.g. through the tightening of controls), HACCP and water safety plans in general, will only be useful if they lead to a demonstrable and actionable improvements either in understanding or in the design or operation of a water supply system. If the approach is to be truly proactive, water suppliers should try to avoid identifying hazards retrospectively to suit existing controls; otherwise the exercise may become bureaucratic and tend towards tokenism rather than active risk management.

Perhaps the most critical aspect to HACCP and water safety plans is that these may inadvertently become exercises in documenting something that companies already do rather than a step change in the approach to managing risk. A salutary lesson for risk managers can be learned from commentaries on the implementation of the international quality standard ISO 9000 (Seddon, 2000; Hoyle, 2001). Hoyle (2001) argues that although some organisations used the standard wisely, for many, it became a 'badge on the wall' 
1 with little to do with improving performance. Some believed the standard was only about documenting what

2 they did. Moreover, the persistence of auditors to require documentation led to situations where

3 documentation only existed in case something went wrong. A similar point is made by Hrudey and Hrudey

4 (2004) regarding HACCP, namely that if it is pursued primarily for public relations, little risk reduction may

5 be achieved.

6

\section{Multiple barrier approach}

Although many would contend that the HACCP system does not preclude a 'multiple barrier' approach to water quality management, arguably neither does it really promote this line (Nokes and Taylor, 2003). In developing their water safety plans, many water suppliers/administrators have sought to take a broader perspective, looking at the widest possible range of 'preventative' or 'control measures' from catchment to tap to protect the public. These can include qualitative checks and measures such as the regular inspection of catchment areas as well as continuous on-line monitoring. For example, the WHO recently set out an authoritative ten-step process for developing safety plans for water systems (WHO, 2004). As with the NHMRC (2004) guidelines, this advocates that water suppliers focus on the broadest possible range of 'control measures'. In the UK, a set of frameworks and guidance material has recently been published to help water companies implement water safety plans from catchment to tap (UKWIR, 2003). Again the focus has been placed on 'risk reduction measures' rather than CCPs for hazards. A practical set of guidelines has also been developed by the New Zealand Ministry of Health (NZMOH, 2001). This promotes the concept of multiple barriers although here, a conscious decision was made to focus on hazard identification by reference to the initiating events or situations that may lead to hazards being introduced in the water. As reviewed by Pollard et al. (2004), the NZMOH approach targets smaller systems and may be particularly valuable for systems with limited technical resources. The rationale behind the NZMOH framework is explained in Nokes and Taylor (2003). They reflect that for smaller water suppliers, whose operational staff may be less familiar with water quality issues, it may be simpler for them to try to prevent certain, well-accepted hazardous events from occurring at the plant level (e.g. the loss of chlorination) rather than trying to direct spare resources to hazards they may know little about and have less control over (e.g. E. coli, Cryptosporidium in catchments). 


\subsection{Assessing barrier integrity}

Once contamination barriers have been identified within a system, water suppliers need to demonstrate their effectiveness continuously either through direct measurement or a programme of spot checks and/or maintenance. Many treatment barriers can be assessed by on-line monitoring and sample analysis. A common means of assessing treatment barriers for the protozoan pathogen Cryptosporidium, for example, is to measure the removal of water turbidity across a treatment process. This is typically cited as a log-removal which conveys the order of magnitude of the removal. For example, '1-log' removal is equivalent to a $90 \%$ reduction, '2-log' equivalent to a $99 \%$ reduction etc. Studies have shown that there is often a direct correlation between the level of particles removed by a process and the removal of microbial pathogens such as Cryptosporidium oocysts (Hamilton et al., 2002). A criticism that could be leveled at some approaches to barrier analysis is that approaches may be driven more by a willingness to comply and less by concern for assessing and managing risk, leading to a progressive overstating of a barrier's effectiveness. Often overlooked is the significance of (a) barrier integrity and (b) barrier independence.

Two concepts that are highly relevant with regard to barrier integrity are 'bad days and bypass' (Gale, 2002). 'Bypass' can be envisaged as ‘spatial variation' where certain areas within each batch (i.e. a proportion of water to be treated) are not treated to the full extent or where raw material continuously contaminates each batch of treated material. In contrast, 'bad days' occur when the overall treatment efficiency falters or fails completely for a time giving rise to 'temporal' variation. Using probabilistic event trees, Gale (2002) shows how ‘bad days’ can have a substantial effect on overall treatment performance. For example, if a process that typically operates at $4-\log (99.99 \%)$ oocyst removal drops down to $1-\log (90 \%)$ removal, say for $5 \%$ of the time, then the net result is that effectively the overall performance of the process is reduced to 2.3-logs (Fig. 1). The net risk of Cryptosporidium oocyst presence in the drinking water supplied to consumers is therefore increased fifty-fold. This can have serious implications in terms of risk management and shows the need to understand and target the weak points in process barriers.

Fig. 1. An example showing impact of ‘bad days’ on overall effectiveness of a treatment process (after Gale, 2002).

'Bypass’ can have a similar deleterious effect on a system. Gale (2002) describes a hypothetical situation where adding extra filtration stages to a treatment process to increase Cryptosporidium oocyst 
removal, yields diminishing returns if a small proportion of raw water bypasses the works in some way e.g. as a result of infiltration within the distribution system. For example, under a scenario where $1 \%$ of the total flow bypasses treatment, a 3-log (99.9\%) or higher removal system is effectively reduced to a 2-log (99\%) system. Examples of bypass within the field of water supply include:

- $\quad$ exposure of populations to microbial pathogens through less tightly regulated private water supplies;

- ingress into water supply distribution systems;

- short-circuiting of raw water storage reservoirs;

- $\quad$ surface water intrusion into groundwater supplies;

- deliberate bypass of a treatment stage; presenting regulatory compliance, for example, to allow otherwise well-run works some leeway, arguably this is not compatible with a true water safety approach. In terms of risk management, emphasis should be placed on identifying weak spots within the process flowsheet and testing worst-case event scenarios and not merely in achieving a level of compliance. Care must be taken not to be complacent when assessing barriers, despite the obvious requirement to satisfy water quality regulators and the public. In order to engender a proactive and transparent culture of risk management within the water supply industry, a different mindset may need to be adopted by water suppliers and regulatory bodies alike when dealing with risk as opposed to straightforward compliance issues.

Barriers should also exhibit a high degree of independency of one another, so that failure of one barrier does not reduce the efficacy of subsequent barriers. In terms of water treatment, a potential problem is posed by flooding or river spate conditions that may have a 'domino effect' in reducing the effectiveness of 
1 trying to maintain optimal coagulant dosing, which in turn can lead to sub-optimal filter performance and

2 increased chlorine demand. This issue is also discussed in LeChevallier and Au (2004). A good example of

3 an independent barrier is the use of ultraviolet (uv) irradiation plants alongside conventional physical barriers

4 (clarification and filtration) to deactivate microbial pathogens in the final water. Although, increased particle

5 numbers in treated water do reduce the effectiveness of uv irradiation, studies by Christensen and Linden

6 (2003) have shown that the effect is negligible in water below 10 NTU turbidity, a level far in excess of most drinking water supplies. In the UK, however, the effectiveness of uv for Cryptosporidium deactivation is not officially recognised in water quality legislation: a water supplier can still potentially be prosecuted if the oocyst concentration exceeds 1 per 10 litres (on average) of drinking water sampled, irrespective of whether they have been deactivated or not (DETR, 1999). Clearly then, managing risks to water safety requires more

11 than the identification of hazards and their control points. It requires an integrated and complete view of the vulnerabilities to the system from catchment to tap.

\section{The US Partnership of Safe Water}

Another significant water safety initiative is the US Partnership of Safe Water. This is a voluntary cooperation formed jointly in 1995 by the US Environmental Protection Agency, the American Water Works Association and several other drinking water organisations with over 200 surface water treatment works in the US currently participating in the scheme (AWWA, 2005). The Partnership currently recognises four levels of accreditation. It has evolved separately from HACCP and although it is not intended to be directly analogous, does have some elements in common with a water safety approach, such as the focus on 'performance limiting factors', which has some similarity to the 'preventative measures' of Nokes and Taylor (2003). However, unlike other water safety plans, the Partnership is not 'risk-based' in the sense that it does not adopt risk assessment as a starting point for risk management. WHO (2004) concedes that some elements of a water safety plan will often be implemented as part of drinking water suppliers' usual practice, but that existing systems may not include tailored hazard identification as a starting point for risk management. It is possible that the Partnership's code could yet be broadened to incorporate more elements of proactive hazard identification and risk management thereby elevating it to a full water safety approach. That is not to say that 
encourages good practice and, if successful in effecting net reductions in turbidity, for example, should lead to significant lowering of microbial risk at high risk works. Moreover, the quality assurance provided by the Partnership is deemed to be highly credible, having been informed and authenticated by an independent third party group. Arguably, in a regulated system, it is unlikely that all optimisation programmes will be determined uniquely through companies' own risk assessment projects. Works' design and operation will continue to be influenced by new regulatory standards and 'good practice' guides such as that provided by the Partnership and other expert groups, reviews and inquiries (e.g. Badenoch, 1990, 1995; Bouchier, 1998). This suggests that although initiatives such as the Partnership for Safe Water may benefit from a stronger focus on risk, conversely they may also themselves contain elements that would be useful additions to any water quality management system.

\section{An integrated approach to water safety}

In order to fully provide "good, safe drinking water that has the trust of customers", water companies need to adopt an integrated approach to managing their supplies, one that not only includes a water safety plan at its core, but that also encompasses a suite of other monitoring, control and other risk assessment initiatives. One way in which this can be conceptualised is to use the framework proposed in Fig. 2. Its premise is that an effective approach to water quality management is characterized at least by the following seven elements:

- Risk assessment - A sensible approach to water safety should proactively and continuously seek out threats to water safety and assess risks in terms of perceived likelihood and consequence. This process typically includes activities such as hazard identification and semi-quantitative risk ranking, but could feasibly encompass a range of other analytical tools e.g. complex GIS models (MacGillivray et al., 2005).

- System controls - Risks can be reduced or eliminated only by improving the water supply system from catchment to tap, according to time and cost constraints. This can include tightening management controls (e.g. staff training) as well as operational controls (process design and operation) as promoted in Awwa (2005). 
- $\quad$ System monitoring - a key component of water safety is the monitoring (through sample testing and on-line monitors) of water quality indicators at different stages in the water supply system. This may be conducted to meet legislative and regulatory requirements or for companies' own purposes of internal quality control or research. "Monitoring” can also include qualitative assessments of water quality (e.g. taste and odour tests) as well as routine spot checks of equipment, constructions and areas (e.g. security checks, reservoir inspections and catchment surveys).

- $\quad$ Risk controls - These refer to control measures undertaken specifically as part of a risk management programme. Not all of these can or need to be monitored. These may include absolute barriers where the hazard is removed or eliminated.

- $\quad$ Risk monitoring - Conversely, not all risks deemed to be significant may be controlled. These can include 'watched risks' believed by the supplier to be borderline, or high risks where no adequate controls currently exist. The risk monitoring process can be complemented by quantitative techniques (e.g. extreme value probability plotting for microbial pathogens, Ongerth, 1989). This can be useful as long as the 'systems-view' ethos of water safety plans is not compromised i.e. that suppliers do assume that a supply is safe solely from its monitoring record.

- Monitor-based controls - It is proposed that some of these initiatives (e.g. statistical process control, turbidity improvement programmes, works intake protection monitoring) have such an importance within the field of quality management that they should be considered in their own right, irrespective of whether or not they are explicitly 'risk-based' and included within water safety plans.

- Barrier validation - The continuous validation of barrier integrity is a key part of water safety plans. This process can include conventional CCP monitoring as well as qualitative site inspections, for example. Aspects which arguably should be given greater emphasis in water safety plans are the importance of 'bad-days and bypass' with regard to barrier integrity, the possible interaction between certain controls, and the level of residual risk in the system.

Fig. 2. A conceptualisation of different water quality management initiatives and their inter-relationship 
In terms of water safety plans, the areas within the risk management section of the model are the most relevant. This is predicated on the basis that it is the proactive and preventative aspects of such an approach that are water safety plans' key features or selling points. However, other initiatives carried out as part of 'good practice' can also play an important in quality management. The conceptualisation provided can be used as a framework for organising and integrating all these initiatives.

\section{Links to other areas of business}

As with many other utility sectors, water suppliers are increasingly seeking to establish sound risk governance throughout all levels of the business to safeguard the interests of their customers and investors. To this end, different risk assessment tools and techniques have been developed that facilitate a consistent approach to risk management across companies, thereby promoting an 'integrated' approach where risk information can be read across from one business area to another.

In England and Wales, for example, water companies are required to adopt a risk-based approach in other areas of regulated business, such as in their obligation to develop and implement 'Distribution Operation and Maintenance Strategies' (DOMS) for the proactive management of drinking water distribution systems (Drinking Water Inspectorate, 2002). A risk analysis approach is also advocated by the financial regulator as a means to prioritise future capital maintenance (Office of Water Services, 2002). Because of the similarity of the risk scoring systems used in these and other initiatives, it would be sensible for a company to standardize its approach to assessing risk in these areas and, where possible, to encourage 'read-across' between them. To this end, many companies are now developing their own asset and/or business risk scoring systems that allow them to prioritise risks to their company. Leverett (2003) details how Severn Trent Water (UK) continuously assesses routine and non-routine tasks in four categories according to their likelihood and impact on water quality, water quantity, health and safety, and the environment. Those risks considered to be significant are linked to the company's risk management database, allowing information to be shared across the company, and a central tracking of risk management actions. Similarly, Scottish Water have developed an interrelated asset risk and criticality scoring mechanism that assesses the 'total business impact' of asset failures across the company in relation to its core business objectives (Lifton and Smeaton, 2003, 2005). This is in essence a source-to-tap FMECA (Failure Mode and Effects Criticality Analysis) approach, but with the 
1 addition of a business impact scoring system that assigns a points' score to different asset failure scenarios according to criteria such as loss of service, environmental impact, and loss of reputation. The result is an integrated system that extends across all levels of the business with the same tools used to prioritise capital investment, plan capital maintenance, as well as develop plant maintenance schedules to minimise the risk of electrical and mechanical failure. Ultimately, the exact shape and form of water safety plan adopted by water companies should be designed with these wider risk management practices in mind.

\section{Conclusions}

The way in which the international water sector manages risk is becoming integrated with other business processes and made more explicit. Risk management is becoming recognised as central to the provision of safe drinking water.

Water suppliers are increasingly seeking to develop and implement proactive and preventative water safety plans in addition to compliance monitoring regimes to improve water safety.

HACCP can be a useful tool in establishing and tightening treatment process controls, but most modern water safety plans have typically sought to extend this further and have adopted a wider-ranging, multiple barrier approach, that looks at a broad range of 'preventative measures' for managing risks from catchment to tap.

The concepts of bad-days and bypass are important within the field of water safety as is barrier independency. A different mindset may need to be taken by water companies and regulators alike to ensure that risks are managed in an effective and transparent way.

Other risk management, optimisation and monitoring initiatives are also important in protecting water supplies. A framework provided can be used to for organizing these into an integrated system.

As the industry moves towards a more integrated approach to managing its risks, the ways in which risk information and strategies are 'read across' to other business areas e.g. capital investment planning is also becoming increasingly important. This should also be a prime consideration for companies when developing their water safety plans.

\section{Acknowledgements}


1 We are grateful to colleagues with whom we have discussed ideas in this paper, including Professor Steve

2 Hrudey (University of Alberta), Roland Bradshaw and Brian MacGillivray (Cranfield University) and

3 representatives of the Institute for Environmental Science and Research (New Zealand), United Utilities

4 (UK), Yorkshire Water (UK) and Water Corporation (Australia). The authors acknowledge the helpful

5 comments of the referees. The opinions expressed herein are the authors' alone.

6

$7 \quad$ References (Accession date for internet addresses)

8 AS/NZS (Australian/New Zealand Standard). AS/NZS 4360:1999 Risk management. Strathfield: Standards Association of Australia; 1999.

10 AWWA (American Water Works Association), EUREAU (European Union of National Associations of Water Suppliers 11 and Waste Water Services), WSAA (Water Services Association of Australia), DVGW (German Associations of Gas

AWWA (American Water Works Association). What is the Partnership for Safe Water? Available at www.awwa.org/science/partnership/overview (accessed May 2005).

Badenoch J. Cryptosporidium in water supplies - First report of the Group of Experts. London: HMSO; 1990.

Badenoch J. Cryptosporidium in water supplies - Second report of the Group of Experts. London: HMSO; 1995.

Baudin I, Laîné JM. Assessment and optimization of clarification process for Cryptosporidium removal. Proceedings of WQTC (Water Quality Technical Conference). San Diego, AWWA (American Water Works Association); November 1998.

Bouchier I. Cryptosporidium in water supplies - Third report of the Group of Experts. London: HMSO; 1998.

Buckley CB. Communications. In: Thompson KC, Gray J, editors. Water contamination emergencies: can we cope? Cambridge: Royal Society of Chemistry, 2004. p. 145-155.

Christensen J, Linden KG. How particles affect UV light in the disinfection of unfiltered drinking water. J. AWWA 2003; 95: 179-189.

CAC (Codex Alimentarius Commission). Hazard analysis and critical control point (HACCP) systems and guidelines for its application. Annex to CAC/RCP 1-1969, Rev 3; 1997. Available at www.fao.org/documents (accessed May 2005).

Cunliffe D. Application of the Australian risk management framework: a public health authorities' perspective. Proceedings of Water safety_ Risk management strategies for drinking water. Berlin: Umweltbundesamt (Federal Environmental Agency); April 2003. 
Deere D, Stevens M, Davison A, Helm G, Dufour A. Management strategies. In: Fewtrell L, Bartram J, editors. Water quality: guidelines, standards and health, London: IWA Publishing; 2001. p. 257-288.

Deere D, Davison A. Safe drinking water - are food guidelines the answer? Water 1998; 25: 21-24.

Deininger RA. Overview of handling emergencies: some cautionary tales. In: Thompson KC, Gray J, editors. Water contamination emergencies: can we cope? Cambridge: Royal Society of Chemistry; 2004. p. 131-138.

DETR (Department of the Environment, Transport and the Regions). Water Supply Regulations (Water Quality) (Amendment), No. 1524. London: HMSO; 1999.

DWI (Drinking Water Inspectorate). Information letter 15/2002. London: DWI; 2002. Available at www.dwi.gov.uk (accessed May 2005).

ENDS (Environmental Data Services) Report (1999) Camelford: questions still unanswered after eleven years. Issue 297. Available at www.environmental-assistance.org/ends/6067.htm (accessed May 2005).

Fawell J. Burncrooks diesel incident. In: Thompson KC, Gray J, editors. Water contamination emergencies: can we cope? Cambridge: Royal Society of Chemistry; 2004. p. 35-37.

14 Fraser R. The Burncrooks Inquiry. Report on the disruption to public water supplies in the area served by Burncrooks Waterworks, December 1997. Edinburgh: The Scottish Office; 1998. Available at www.scotland.gov.uk/library/documents5/burn-00.htm (accessed May 2005).

Furness M. The WEM Incident. In: Thompson KC, Gray J, editors. Water contamination emergencies: can we cope? Cambridge: Royal Society of Chemistry; 2004. p. 11-15.

Gale P. Using risk assessment to identify future research requirements. J. AWWA 2002; 94: 30-37.

Havelaar AH. Application of HACCP to drinking water supply. Food Control 1994; 5: 145-152.

Hamilton PD, Standen G, Parsons SA. Using particle monitors to minimise Cryptosporidium risk: a review. J. Water SRT - Aqua 2002; 51: 351-366.

Hellier K. HACCP at Melbourne Water - Implementation from catchment to tap. Proceedings of Water safety - Risk management strategies for drinking water. Berlin: Umweltbundesamt (Federal Environmental Agency); April 2003.

Hoyle D. ISO 9000 Quality Systems Handbook (Fourth Edition) Oxford: Butterworth Heinemann; 2001.

Hrudey SE, Huck PM, Payment P, Gillham RW, Hrudey EJ. Walkerton: lessons learned in comparison with waterborne outbreaks in the developed world. J. Environ. Eng. Sci 2002; 1:397-407.

Hrudey SE, Hrudey EJ. Safe drinking water - Lessons from recent outbreaks in affluent nations. London: IWA Publishing; 2004.

IWA (International Water Association). The Bonn Charter for safe drinking water. London: IWA; 2004. Available at www.iwahq.org.uk (accessed May 2005). 
ISO (International Organization for Standardization). ISO 9001 Quality management systems - requirements. Geneva: ISO; 2000.

LeChevallier MW, Au KK. Water treatment and pathogen control. Process efficiency in achieving safe drinking water, London: IWA; 2004.

Leverett S. Eating the elephant. Water 2003; 166: 8-9.

Lifton G, Smeaton P. Asset risk management in Scottish Water. Proceedings of the Water Environment Conference: Risk and reward in asset management delivery - who is best prepared for the challenges ahead? London: ICE/CIWEM; November 2003.

Lifton G, Smeaton P. Risk and asset management - the interface. Risk analysis strategies for better and more credible decision-making: project overview and progress. Proceedings of Risk analysis strategies for better and more credible decision-making. Banff: AwwaRF, Cranfield University; ISBN 1-861941-15-3; April 2005.

Lisle JT, Rose JB. Cryptosporidium contamination of water in the USA and UK: a mini-review. J. Water SRT - Aqua 1995; 44: 103-117.

14 MacGillivray BH, Hamilton, PD, Strutt, JE, Pollard, SJT Risk analysis strategies in the water utility sector: an inventory of applications for better and more credible decision-making. Critical Reviews in Environmental Science and Technology; in press.

17 McClellan P. Sydney Water Inquiry. Australia: New South Wales Premier’s Department; 1998.

18 Metge S, Brodard E, Conan M. Lyonnaise des Eaux: application of HACCP principles for in drinking water. Proceedings of Water safety - Risk management strategies for drinking water. Berlin: Umweltbundesamt (Federal Environmental Agency); April 2003.

Mullenger J, Ryan G, Hearn J. A water authority’s experience with HACCP. Wat. Sci. Tech: Wat. Supply 2002; 2: 149155.

NHMRC (National Health and Medical Research Council). Australian drinking water guidelines. Canberra: NHMRC;

25 NHMRC. Framework for Management of Drinking Water Quality. Canberra: NHMRC; 2001.

26 NHMRC. Australian drinking water guidelines - Draft. Canberra: NHMRC; June 2002.

27 NHMRC. Australian drinking water guidelines. Canberra: NHMRC; 2004 Available at 28 www.health.gov.au/nhmrc/publications/synopses/eh19syn.htm (accessed May 2005).

29 NZMOH (New Zealand Ministry of Health). How to prepare and develop public health risk management plans for 30 drinking-water supplies. Wellington: Ministry of Health; 2001. Available at www.moh.govt.nz/moh.nsf (accessed May 2005). 
Nokes C, Taylor M. Towards public health risk management plan implementation in New Zealand. Proceedings of Water safety - Risk management strategies for drinking water. Berlin: Umweltbundesamt (Federal Environmental Agency); April 2003.

Ofwat (Office of Water Services). Maintaining water and sewerage systems in England and Wales. Birmingham: Ofwat; 2002. Available at www.ofwat.gov.uk (accessed May 2005).

O’Connor DR. The events of May 2000 and related events. Report of the Walkerton Inquiry (Part 1). Toronto: Ontario Ministry of the Attorney General; 2002.

Ongerth JE. Giardia cyst concentrations in river water. J. AWWA 1989; 81: 81-86.

Pollard SJT, Strutt JE, MacGillivray BH, Hamilton PD, Hrudey SE. Risk analysis and management in the water utility sector - a review of drivers, tools and techniques. Trans. Inst. Chem. Eng. Part B, Process Safety Environ. Protect. 2004; 82:453-462.

Pollard SJT, Hamilton PD, Hrudey SE, Strutt JE, MacGillivray BH, Bradshaw R, Sharp JV, Leiss W, Reekie L, Godfree A. Risk analysis strategies for better and more credible decision-making: project overview and progress. Proceedings of Risk analysis strategies for better and more credible decision-making. Banff: AwwaRF/Cranfield University; ISBN 1-861941-15-3; April 2005.

Seddon J. The case against ISO 9000. Springfield; Oak Tree Press; 2000.

Smith HV, Smith AL, Girdwood RWA, Carrington EG. The effect of free chlorine on the viability of Cryptosporidium sp oocysts isolated from human faeces. In: Badenoch J, editor. Cryptosporidium in Water Supplies. London: HMSO; 1990.

Solo-Gabriele H, Neumeister S. US Outbreaks of cryptosporidiosis. J. AWWA 1996; 88: 76-86.

Stevens M. Water Safety Plan: the WHO approach. Proceedings of Water safety - Risk management strategies for drinking water. Berlin: Umweltbundesamt (Federal Environmental Agency); April 2003.

UKWIR (United Kingdom Water Industry Research). Managing microbial and chemical risks from source to tap. Report Ref. No. 03/DW/02/31. London: UKWIR Limited; 2003.

Walker R. Risk management - the realities of implementation. Proceedings of Risk analysis strategies for better and more credible decision-making. Banff: AwwaRF and Cranfield University, 2005; 6-8 ${ }^{\text {th }}$ April, 2005.

WHO (World Health Organisation). Guidelines for drinking water quality - $3^{\text {rd }}$ Edition. Geneva: WHO; 2004. Available 


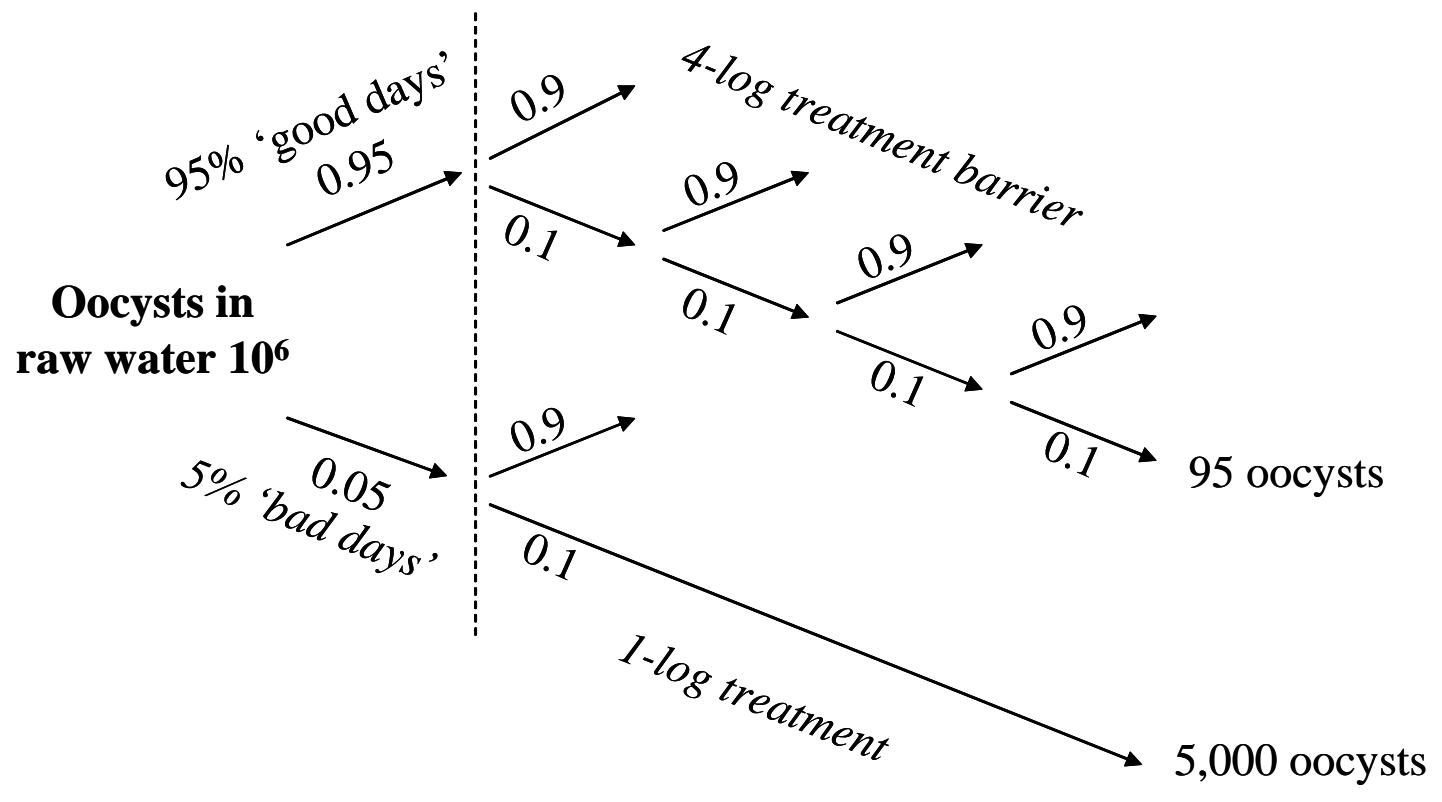

Total exposure 5095 oocysts Net reduction in exposure $=2.29$ logs 


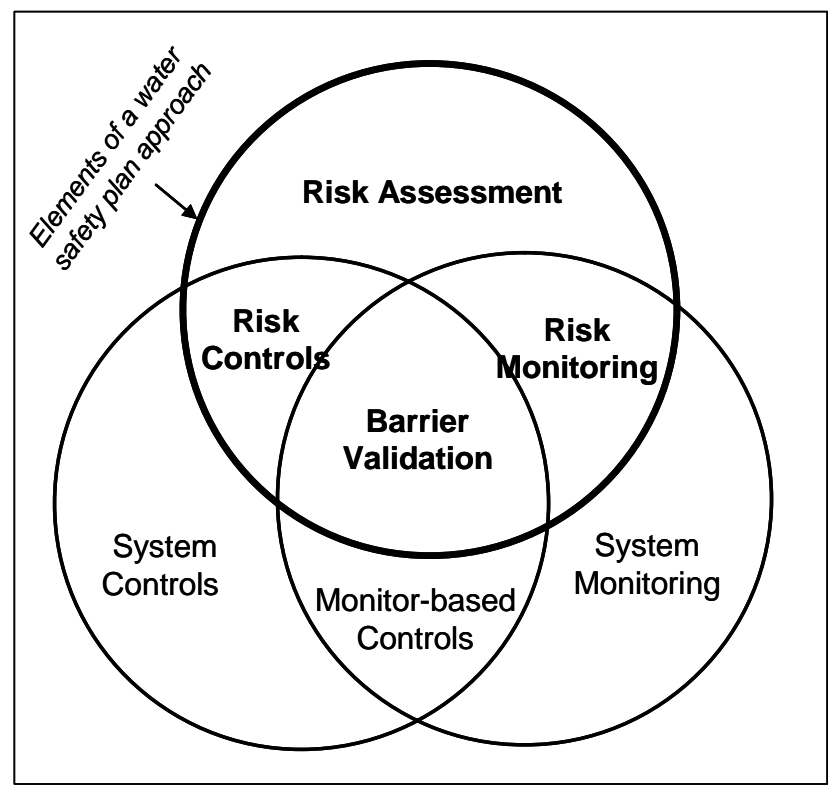


2 Some documented water quality incidents

\begin{tabular}{|c|c|c|c|c|}
\hline Incident & Location & Year & Cause and Impact & Ref \\
\hline \multirow[t]{4}{*}{$\begin{array}{l}\text { Microbial } \\
\text { contamination of } \\
\text { drinking water }^{1}\end{array}$} & Milwaukee, USA & 1993 & $\begin{array}{l}\text { Sub-optimum design and operation of a water treatment works was suspected to have been responsible for a } \\
\text { massive outbreak of cryptosporidiosis, believed to have affected up to } 400,000 \text { people and left } 69 \text { dead, although } \\
\text { these numbers are disputed. Factors that may have contributed to the outbreak include the recycling of used filter } \\
\text { washwater back to the head of the works. }\end{array}$ & $\begin{array}{l}\text { Lisle and Rose (1995) } \\
\text { Solo-Gabriele and Neumeister (1996) } \\
\text { Deininger (2004) } \\
\text { Hrudey and Hrudey (2004) }\end{array}$ \\
\hline & Gideon, USA & 1993 & $\begin{array}{l}\text { An outbreak of Salmonella is believed to have arisen when droppings from nesting pigeons fell into in an open } \\
\text { and disused, private water storage tank. These accumulated droppings are thought to have been washed into the } \\
\text { drinking water during a programme of mains flushing. Around } 500 \text { people became ill and } 7 \text { elderly people died. }\end{array}$ & $\begin{array}{l}\text { Deininger (2004) } \\
\text { Hrudey and Hrudey (2004) }\end{array}$ \\
\hline & Sydney, Aus & 1998 & $\begin{array}{l}\text { High concentrations of Cryptosporidium and Giardia (oo)cysts were found in a works' raw and treated water. } \\
\text { No incidence of disease was reported, although a boil water notice was issued to residents. The official incident } \\
\text { report criticised delays in alerting the public to the potential health risks and recommended a critical examination } \\
\text { of procedures to communicate these to the public. }\end{array}$ & $\begin{array}{l}\text { McClellan (1998) } \\
\text { Hrudey and Hrudey (2004) }\end{array}$ \\
\hline & Walkerton, Can & 2000 & $\begin{array}{l}\text { Around 2,300 residents were ill and } 7 \text { died from drinking water contaminated with } E \text {. coli } \mathrm{O} 157: \mathrm{H} 7 \text { and } \\
\text { Campylobacter jejuni. The contamination was traced to the run-off from a local farm which had infiltrated a } \\
\text { nearby well. Chlorine residuals were not being maintained with operators failing to carry out simple checks and } \\
\text { falsifying records. }\end{array}$ & $\begin{array}{l}\text { O’Connor et al. (2002) } \\
\text { Deininger (2004) } \\
\text { Hrudey and Hrudey (2004) }\end{array}$ \\
\hline \multirow{3}{*}{$\begin{array}{l}\text { Chemical } \\
\text { contamination of } \\
\text { drinking water }\end{array}$} & Camelford, UK & 1988 & $\begin{array}{l}\text { A stand-in delivery tanker driver pumped } 20 \text { tons of aluminium sulphate directly into the final chlorine contact } \\
\text { tank at an unmanned works. }\end{array}$ & $\begin{array}{l}\text { Environmental Data Services (1999) } \\
\text { Buckley (2004) }\end{array}$ \\
\hline & Worcester, UK & 1994 & $\begin{array}{l}\text { Water supplied from a river abstraction works became tainted with low concentrations of a industrial solvent, } \\
\text { which had passed through an upstream sewage treatment works. This led to taste and odour problems, } \\
\text { inconveniencing around } 110,000 \text { customers over a two-day period. No illnesses or health risks were believed to } \\
\text { have resulted from this incident. }\end{array}$ & Furness (2004) \\
\hline & Glasgow, UK & 1997 & $\begin{array}{l}\text { Around } 200 \text { litres of diesel were spilled during an unmanned fuel transfer to a mobile generator at a water } \\
\text { treatment works. Unbeknownst to the treatment operator, the drain into which this spillage had entered, fed } \\
\text { directly into the works' washwater recovery system. The problem lay unrecognised for } 24 \text { hours. The water } \\
\text { supply to } 60,000 \text { customers was affected and the water deemed unfit to drink for } 8 \text { days. }\end{array}$ & $\begin{array}{l}\text { Fraser (1998) } \\
\text { Fawell (2004) }\end{array}$ \\
\hline
\end{tabular}


